\title{
Colorectal Cancer in Iran: A Retrospective, Comparative Study of Early-onset and Late-onset Cases in north-eastern Iran based on the Iranian Hereditary Colorectal Cancer Registry
}

\section{Benyamin Hoseini}

Mashhad University of Medical Sciences

\section{Zahra Rahmatinejad}

Mashhad University of Medical Sciences

\section{Ladan Goshayeshi}

Mashhad University of Medical Sciences

\section{Robert Bergquist}

Swiss Tropical and Public Health Institute

\section{Fatemeh Rahmatinejad}

Mashhad University of Medical Sciences

\section{Amin Golabpour}

Shahroud University of Medical Sciences

\section{Kamran Ghaffarzadegan}

Mashhad University of Medical Sciences

\section{Reza Darrudi}

Neyshabur University of Medical Sciences

\section{Saeid Eslami ( $\nabla$ saiedeslami67@gmail.com )}

Mashhad University of Medical Sciences

\section{Research Article}

Keywords: early-onset CRC, colon cancer, colorectal cancer, mismatch repair, cancer screening, registry

Posted Date: January 6th, 2021

DOl: https://doi.org/10.21203/rs.3.rs-137344/v1

License: (1) This work is licensed under a Creative Commons Attribution 4.0 International License. Read Full License 


\section{Abstract}

Background: Generally, the incidence rate of colorectal cancer (CRC) is increasing among young patients (aged $<49$ years), while the reasons for the rising incidence are unclear. Indicative variables, such as tumour location, gender preference and genetic preponderance have not been followed up in a consistent manner. The current study was primarily conducted to improve the hereditary CRC screening programme by assessing the demographic and pathological characteristics of early-onset CRC compared to lateonset CRC in northeast Iran.

Methods: This retrospective study was carried out over a three-year follow-up period (2014-2017) and included 562 CRC patients in three Mashhad City hospital laboratories in north-eastern Iran. We applied comparative analysis of pathological and familial features together with information on the presence of genetic mismatch repair-deficiency in relation to final patient status (surviving versus deceased cases). Analyses using R studio software were performed on early-onset CRC $(n=222)$ and late-onset CRC $(n=340)$ groups produced by division at the age of 50 years.

Results: From an age-of-onset point of view, the distribution between the genders differed with females showing a higher proportion of early-onset CRC compared to men ( $56 \%$ vs. $44 \%$ ), while the late-onset CRC disparity was less pronounced ( $48 \%$ vs. $52 \%$ ). The mean age of all participants was $55.6 \pm 14.8$ years, while it was $40.3 \pm 7.3$ years for early-onset CRC and $65.1 \pm 9.3$ years for late-onset CRC. With respect to anatomical tumour location (distal, rectal, and proximal), the frequencies were $61 \%, 28 \%$ and $11 \%$, respectively, but the variation did not reach statically significance. There was a dramatic difference with regard to the history of CRC in second-degree relatives (SDR) and that of the combination of firstdegree relatives and SDR ( $p=0.001$ and $p=0.03$, respectively). Expression of the MLH1 and PMS2 genes were significantly different between survivors and deceased, however this finding was not observed with regard to the MSH6 and the MSH2 genes.

Conclusion: The variation of demographic, pathological and genetic characteristics of CRC between earlyonset and late-onset cancers of this kind emphasizes the need for a well-defined algorithm to identify high-risk patients.

\section{Introduction:}

Colorectal Cancer (CRC) is the second leading cause of mortality and the fourth most common cancer, accounting for $9.2 \%$ of all cancer mortality worldwide [1]. It thus represents a notable source of morbidity, mortality and impediment to life expectancy; approximately, 1.2 million people suffer from CRC, whose incidence rate per 100,000 of $20-49$ years olds increased by $1.5 \%$ per year among males and $1.6 \%$ per year among females between 1975 and 2010 [2, 3]. More recently, screening for CRC and other lowerintestine disorders by colonoscopy has contributed to a decrease of CRC incidence through the detection and elimination of precancerous polyps. On the other hand, this is not evident in those less than 50 years old, and early-onset CRC is now considered a major health issue [4]. Current studies show that $94 \%$ of 
early-onset CRCs are discovered and diagnosed after presenting with symptoms - the most predominant ones being abdominal/rectal pain and bleeding - indicating an advanced stage with poor outcome $[5,6]$.

The reasons for the rising incidence and mortality of early-onset CRCs are unclear. Some authors suggest that the growing trend may be related to changing lifestyles, with an increasingly common type of patients characterized by overweight as evidenced by a body mass index (BMI) above 25, low physical activity and diabetes $[7,8]$. Biologically, CRC in young patients may be different from that seen in patients above 50 years of age. Previous studies have shown that CRC is mainly left-sided in young patients [9, $10]$ and particularly common in distal colon and rectum $[9,10]$.

Based on the Surveillance, Epidemiology and End Results (SEER) programme in the U.S. (https://seer.cancer.gov/), 15\% of all CRCs are diagnosed in patients under 50 years of age; moreover it has been predicted that this cancer would increase until 2030 resulting in up to $90 \%$ more colon cancer cases and $124 \%$ more rectal cancer in patients 20 to 34 years old [11]. According to several studies, earlyonset CRC incidence varies between different areas in the world with nearly $20 \%$ of cases found in Asia including the Middle East (where it is diagnosed in less than 40-year olds) as compared to $2-8 \%$ reported from the U.S. $[12,13]$. Compared to western countries, the incidence of CRC is currently very low in the older Iranian population, while young Iranians are showing a rising trend [5]. In addition, advanced stage $\mathrm{CRC}$ with atypical histology has become more likely to be recognized in younger patients, who need more aggressive therapies compared to older individuals [14].

GLOBOCAN 2018 tells us that the incidence of CRC could double in Iran before 2040 [15]. Considering the growing trend of this disease, we need to integrate knowledge of early-onset CRC tumour characteristics and differences to develop more precise and individualized screening and treatment strategies. So far, to gain a deeper understanding of this upcoming world-wide health issue, the differences between earlyonset and late-onset CRCs have been investigated in various populations and ethnics $[16,17]$. While the pathogenesis of former in the context of hereditary syndromes, as well as sporadic cases, have been widely studied in the western part of the world [18-22], epidemiological data and pathogenesis of this type of cancer is generally lacking in countries situated in the East [23]. Moreover, there are considerable diversities regarding tumour location, gender preference and survival [24-28], which need to be specified for the region. For example, it would be useful to know more about the geographical aspect, for example whether or not there are clusters with higher incidence of early-onset CRC [29, 30].

Among its priorities, the Iranian Hereditary Colorectal Cancer Registry (IHCCR) aims to detect, register and follow patients with hereditary CRC in Iran. So far, identification of CRCs and colorectal adenomas at high risk of developing into hereditary CRC [31-33] is recommended, but this may not be enough. The current study was conducted to assess the demographic, genetic and pathological characteristics of early-onset CRC compared to late-onset CRC in Iran, specifically to improve screening for hereditary CRC.

\section{Materials And Methods:}




\section{Study design and scope:}

We approached the problem through a retrospective, cross-sectional study that was performed from April 2014 to February 2017 in Mashhad City in north-eastern Iran. Our study was aimed to investigate various measurements based on the Amsterdam II [34] and the revised Bethesda [35] criteria, guidelines aimed at improving identification of individuals likely to have the Lynch syndrome, also known as hereditary nonpolyposis colorectal cancer (HNPCC), and therefore at increased risk of developing CRC [31-33]. We also analyzed available data in survivors and non-survivors with respect to gender, anatomical tumour location, status of potential genetic mismatch repair (MMR)-deficiency in relation to age, CRC history in first degree relatives (FDR) and in second degree relatives (SDR) as well as non-CRC history in FDR and general family history of cancer (FHC). The genetic part of the study focused on the four MMR protein products of the genes MLH1, MSH2, MSH6 and PMS2 identified by immunohistochemistry (IHC) screening as described earlier [31, 32]. An IHC screening was deemed abnormal if the IHC staining was absent. For experiments involving human participants (including the use of tissue samples), the participants signed an informed consent before the study.

\section{Setting and Study Population:}

All CRC patient information was obtained from three referral centres including Imam Reza Hospital Laboratory, Mashhad Pathology Laboratory and Moayed Pathology Laboratory in Mashhad City. Data on individuals without firm age information were discarded from the study. With respect to other missing data, we considered each available item for each category and included also some variables with missing data as shown in Fig. 1 that illustrates the exclusion/inclusion process. Because of changing availability of variables we ended up with different numbers of patients in the different categories.

\section{Statistical analyses:}

The Chi-square test and the Fisher exact test were employed to identify any statistically significant differences in baseline characteristics in relation to age. The data were presented as percentage frequency of categorical variables and with mean standard deviation (SD) for continuous variables. $P$ values $<0.05$ were considered statistically significant. All analyses were performed in $\mathrm{R}$ studio (https://rstudio.com/).

\section{Results:}

As seen in Fig. 1, a total of 562 CRCs were included in the study. The patients were divided into two categories: early-onset $(n=222)$, i.e. CRC diagnosed in those $\leq 50$ years old; and late-onset $(n=340)$, i.e. CRC diagnosed in those $>50$ years old. The outcomes in relation to the different characteristics studied for these two age categories are shown in Table 1. 
The participants' ages ranged from 20 to 90 years with a mean age of $55.63 \pm 14.8$ years. In the earlyonset CRC group, the mean age was $40.34 \pm 7.3$ years, while it was $65.11 \pm 9.3$ years in the late-onset group. The overall gender distribution was close to equal ( $51 \%$ females vs. $49 \%$ males), however there was a statistically significant difference between the two age categories at the $0.03 p$-level. With respect to the early-onset CRC and late-onset CRC categories, there was a $55.9 \%$ vs. $48.2 \%$ disparity among the female patients and a $44.1 \%$ vs. $51.8 \%$ one for the men, respectively. Interestingly, women made up the majority of early-onset CRCs compared to the late-onset ones (Table 1).

As shown in Table 1, the anatomical tumour location varied considerably between the two types of CRC, but did not reach statistical significance, although it was evident that distant colon tumours were in majority, particularly in late-onset CRC.

The Amsterdam II HNPCC criteria were mostly present among the early-onset CRCs $(66.6 \%)$ and $42 \%$ of them had MMR-deficiencies as well. About $85 \%$ of patients had no history of CRC, neither in FDR nor in SDR and around $15 \%$ of 419 CRCs had non-CRC history of cancer in FDR, the most common being gastric cancer, breast cancer and lung cancer. Generally, there was no statistically significant difference between the early-onset CRC and late-onset CRC groups with respect to history of CRC and non-CRC in FDR, however there was a drastic difference with regard to history of CRC in SDR and the combination of FDR and SDR ( $p=0.001$ and $p=0.03$, respectively). Among 409 CRCs, nearly 33\% had reported FHC, while $20 \%$ of 293 CRC patients passed away, a fact that was significantly more common among late-onset CRCs than the early-onset CRC ones $(p=0.03)$.

In terms of molecular characteristics, 41 of $421 \mathrm{CRCs}$, who had undergone IHC investigation, had one or more kinds of MMR-deficiencies at a frequency for early-onset CRC of 18 compared to 23 for late-onset disease. Although the percentage of MMR-deficiency in the early-onset CRC group was greater than that in the late-onset one ( $11.2 \%$ vs. $8.9 \%)$, this difference was not significant. 
Table 1

Baseline characteristics of the study participants

\section{Characteristics}

$\operatorname{Gender}^{*}(n=562)$

Female $(n=288)$

Male $(n=274)$

Tumour location $(n=454)$

Proximal $(n=50)$

Distal $(n=276)$

Rectum $(n=128)$

Amsterdam $\|^{\star}(n=411)$

Criteria absent $(n=396)$

Criteria present $(n=15)$

Revised Bethesda* $(n=408)$

Criteria absent $(n=212)$

Criteria present $(n=196)$

History of CRC in FDR* $(n=411)$

NO $(n=375)$

Yes $(n=36)$

History of CRC in $\operatorname{SDR}^{*}(\mathrm{n}=419)$

No $(n=383)$

Yes $(n=36)$
Early-onset CRCs (\%)

124 (55.9)

$98(44.1)$

$13(8.4)$

$93(60.0)$

49 (31.6)

151 (93.8)

$10(6.2)$

244 (98.0)

$5(2.0)$

$13(8.0)$

$150(92.0)$

199 (81.2)

$46(18.8)$

148 (91.4)

227 (91.2)

$0.54^{\mathrm{a}}$

$14(8.6)$

$22(8.8)$

$142(85.5)$

241 (95.3)

$0.001^{\mathrm{a}}$

24 (14.5)

$12(4.7)$

$P$-value

$0.03^{\mathrm{a}}$

$0.15^{b}$

183 (61.2)

79 (26.4)

$0.03^{\mathrm{a}}$

$0.001^{a}$

64 (48.2)

176 (51.8)

$37(12.4)$

(1) 


\begin{tabular}{|c|c|c|c|}
\hline Characteristics & Early-onset CRCs (\%) & Late-onset CRCs (\%) & $P$-value \\
\hline History of CRC in FDR or SDR ${ }^{*}(n=414)$ & $122(79.2)$ & $225(86.5)$ & $0.03^{a}$ \\
\hline NO $(n=347)$ & $32(20.8)$ & $35(13.5)$ & \\
\hline \multicolumn{4}{|l|}{ Yes $(n=67)$} \\
\hline History of non-CRC in FDR* $(n=419)$ & $143(86.1)$ & $214(84.6)$ & $0.38^{\mathrm{a}}$ \\
\hline NO (no = 357) & $23(13.9)$ & $39(15.4)$ & \\
\hline \multicolumn{4}{|l|}{ Yes $(n=62)$} \\
\hline $\mathrm{FHC}^{*}(n=409)$ & $107(66.5)$ & $169(68.1)$ & $0.4^{\mathrm{a}}$ \\
\hline Absent $(n=276)$ & $54(33.5)$ & $79(31.9)$ & \\
\hline \multicolumn{4}{|l|}{ Present $(n=133)$} \\
\hline Survival study group $(n=293)$ & $103(85.8)$ & $131(75.7)$ & $0.03^{\mathrm{a}}$ \\
\hline Alive $(n=234)$ & $17(14.2)$ & $42(24.3)$ & \\
\hline \multicolumn{4}{|l|}{ Deceased $(n=59)$} \\
\hline Mismatch repair status ${ }^{*}(n=421)$ & $143(88.8)$ & $237(91.1)$ & $0.39^{a}$ \\
\hline Proficient $(n=380)$ & $18(11.2)$ & $23(8.9)$ & \\
\hline \multicolumn{4}{|l|}{ Deficient $(n=41)$} \\
\hline Type of treatment ${ }^{\star}(n=124)$ & $7(15.0)$ & $23(30.0)$ & $0.1^{\mathrm{b}}$ \\
\hline Surgery $(n=30)$ & $6(13.0)$ & $13(17.0)$ & \\
\hline Chemotherapy $(\mathrm{n}=19)$ & $33(72.0)$ & $42(53.0)$ & \\
\hline Chemo-surgery $(n=75)$ & & & \\
\hline
\end{tabular}

Abbreviations: $\mathrm{CRC}=$ Colorectal Cancer; FDR = First Degree Relatives; $\mathrm{SDR}=$ Second Degree Relatives; $\mathrm{FHC}=$ Family History of Cancer; MMR = mismatch repair.

*Indicating variables with missing value

** Some of the 41 CRCs mismatch repair-deficiencies had loss of expression in more than one protein, which explains that the sum of the loss of expressions of the four proteins exceed 41.

a Analysis by Fisher's exact test

${ }^{b}$ Analysis by Chi-square test 


\begin{tabular}{|c|c|c|c|}
\hline Characteristics & Early-onset CRCs (\%) & Late-onset CRCs (\%) & $P$-value \\
\hline${ }^{\star \star}$ MMR-deficiency ( $\mathrm{n}=41$ ( & $18(43.9)$ & $23(56.1)$ & $0.3^{\mathrm{a}}$ \\
\hline MLH1 $(n=27)$ & $13(48.1)$ & $14(51.9)$ & \\
\hline PMS2 $(n=30)$ & 13 (43.3) & $17(56.7)$ & \\
\hline MSH2 (n = 9) & $4(44.4)$ & $5(55.6)$ & \\
\hline MSH6 $(n=10)$ & $5(50.0)$ & $5(50.0)$ & \\
\hline \multicolumn{4}{|c|}{$\begin{array}{l}\text { Abbreviations: } \mathrm{CRC}=\text { Colorectal Cancer; FDR = First Degree Relatives; } \mathrm{SDR}=\text { Second Degree Relatives; } \\
\text { FHC = Family History of Cancer; MMR = mismatch repair. }\end{array}$} \\
\hline \multicolumn{4}{|c|}{${ }^{*}$ Indicating variables with missing value } \\
\hline \multicolumn{4}{|c|}{$\begin{array}{l}{ }^{*} \text { Some of the } 41 \text { CRCs mismatch repair-deficiencies had loss of expression in more than one protein, } \\
\text { which explains that the sum of the loss of expressions of the four proteins exceed } 41 .\end{array}$} \\
\hline \multicolumn{4}{|c|}{${ }^{a}$ Analysis by Fisher's exact test } \\
\hline b Analysis by Chi-square test & & & \\
\hline
\end{tabular}

Several features between the survivor and non-survivor groups, including deficient expression of the $\mathrm{MSH} 6$ and $\mathrm{MSH} 2$ genes, the Amsterdam- II/revised Bethesda criteria as well as the tumour location did not reach statistical significance. However, the presence of deficient MLH1 and PMS2 genes as well as risk for developing the Lynch syndrome stood out as variables of high impact. 
Table 2

Various features in the group of patients studied with respect to survival

\begin{tabular}{|c|c|c|c|c|}
\hline Variable & $\begin{array}{l}\text { Survived = } 234 \\
\text { Number (\%) }\end{array}$ & $\begin{array}{l}\text { Deceased = } 59 \\
\text { Number }(\%)\end{array}$ & $\begin{array}{l}\text { Total = } 293 \\
\text { Number (\%) }\end{array}$ & $P$-value \\
\hline Age in years & $43(82.7)$ & $9(17.3)$ & $52(17.7)$ & \multirow[t]{6}{*}{$<0.001^{b}$} \\
\hline$\leq 40$ & $60(88.2)$ & $8(11.8)$ & $68(23.2)$ & \\
\hline $40-49$ & 59 (81.9) & $13(18.1)$ & $72(24.6)$ & \\
\hline $50-59$ & 39 (81.3) & $9(18.8)$ & $48(16.4)$ & \\
\hline $60-70$ & $33(62.3)$ & $20(37.7)$ & $53(18.1)$ & \\
\hline \multicolumn{4}{|l|}{$>70$} & \\
\hline Gender & $156(49.0)$ & $29(49.0)$ & $185(49.0)$ & \multirow[t]{3}{*}{$0.59^{\mathrm{a}}$} \\
\hline Female & $159(51.0)$ & $30(51.0)$ & $189(51.0)$ & \\
\hline \multicolumn{4}{|l|}{ Male } & \\
\hline Amsterdam $~ I^{*}$ & $196(95.1)$ & $53(96.3)$ & $249(95.0)$ & \multirow[t]{3}{*}{$0.7^{a}$} \\
\hline Criteria absent & $10(4.9)$ & $2(3.7)$ & $12(5.0)$ & \\
\hline \multicolumn{4}{|l|}{ Criteria present } & \\
\hline Location $^{*}$ & $17(8.9)$ & $4(7.3)$ & $21(8.5)$ & \multirow[t]{7}{*}{$0.6^{b}$} \\
\hline Caecum & $49(25.7)$ & $11(20.0)$ & $60(24.4)$ & \\
\hline Transverse/descending & $42(22.0)$ & $12(21.8)$ & $54(22.0)$ & \\
\hline Sigmoid & $29(27.2)$ & $18(38.2)$ & $47(29.7)$ & \\
\hline Rectum & $20(10.5)$ & $4(7.3)$ & $24(9.8)$ & \\
\hline Rectosigmoid & $11(5.8)$ & $3(5.5)$ & $14(5.7)$ & \\
\hline Other & & & & \\
\hline
\end{tabular}

Abbreviations: $\mathrm{CRC}=$ Colorectal Cancer; $\mathrm{MMR}=$ Defective DNA mismatch repair; $\mathrm{pMMR}=$ mismatchrepair proficiency; dMMR = mismatch repair-deficiency

* Indicating variables with missing value

a Analysis by Fisher's exact test

${ }^{b}$ Analysis by Chi-square test 


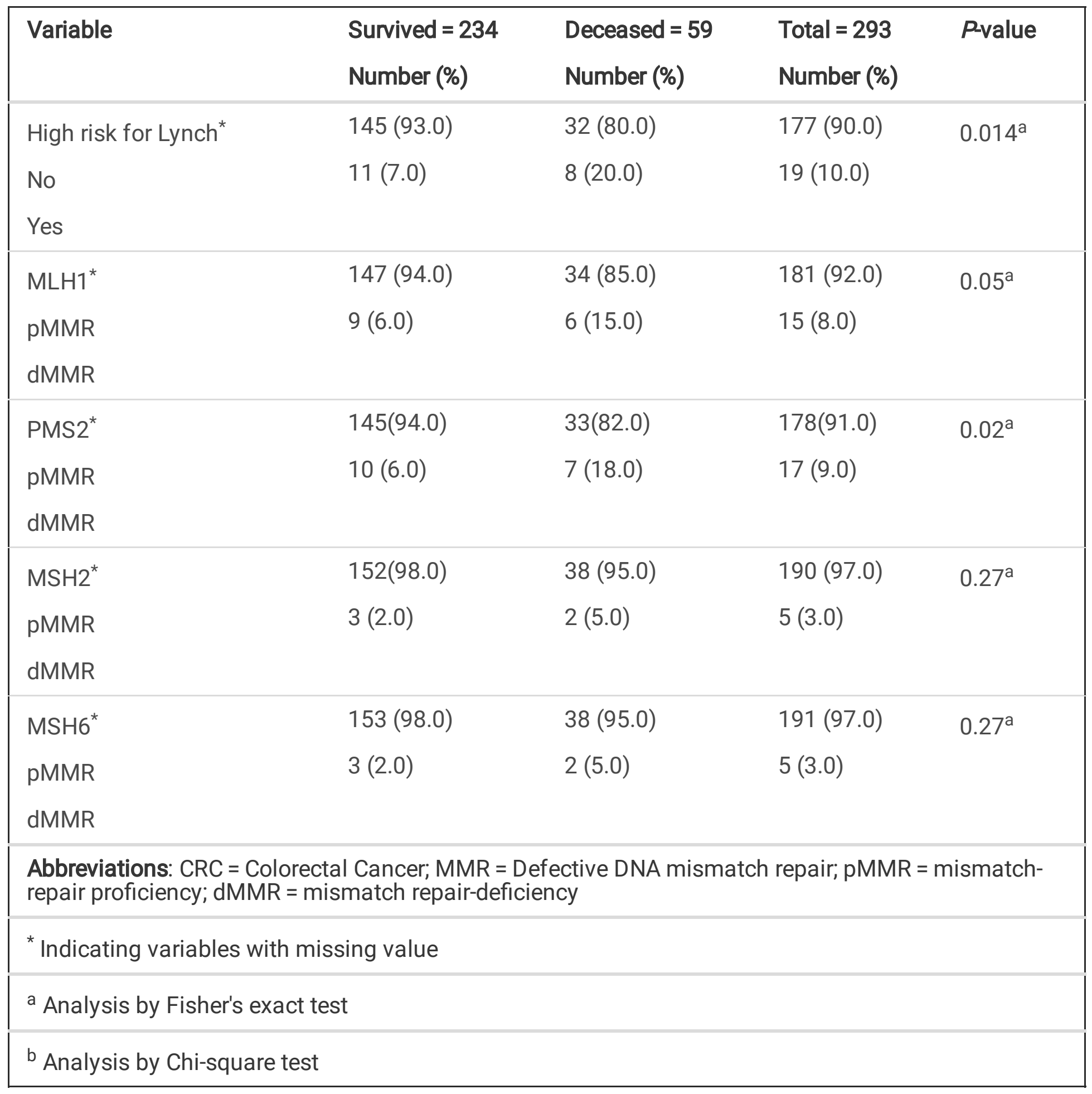

\section{Discussion:}

\section{Main findings:}

In medical circles, CRC has turned into a hot discussion topic worldwide. In spite of the overall decreasing rate of CRC, which is particularly evident for patients older than 50 years [36], the trend is the opposite in younger patients, which highlights the importance of this issue [37]. Multiple studies have focused on clarifying the characterization of CRC based on the age of onset $[3,38]$. It was felt to be useful for a 
retrospective, cross-sectional study to assess the clinicopathological and hereditary features cut-off at 50 years as it falls in the middle of what normally is used.

Although several features (Amsterdam-II, Revised Bethesda, tumour location, deficient expression of the MSH6 and MSH2 genes) did not reach statistical significance, others (deficient MLH1 and PMS2 genes, Lynch syndrome risk) differed dramatically with respect to survival or death. In terms of the latter, most non-survivors were diagnosed with late-onset CRC, and most of those with CRC and high risk of Lynch syndrome were in the non-survivor group.

\section{Comparison to other similar studies:}

Generally, early-onset CRC shows an increasing trend as opposed to late-onset CRC which holds true also at the country level. For example, an Italian study showed that the incidence rate of CRC in patients aged 20-49 years increased from 9.3 in 1957 to 13.7 in 2015, whereas the incidence rate of CRC in patient aged 50 years and above has steadily declined [36]. However, this pattern is more pronounced in Asia than in the Western countries [25,39-45]. Recent studies give incidence rates of CRC in patients at 50 years and younger in India [46] and in the central region of Iran [23] at 39\% and 25\%, respectively. Furthermore, we found that more than $38 \%$ of our cases were first diagnosed with CRC when still under 50 years. Median age in early-onset CRCs was 45 years and the common age range was $40-50$ years which are both similar to other studies.

From the end of the previous decade until today, different researches have studied early-onset CRCs around the world (see Table 3). The median sample size of these studies was 154 with an interquartile range (IQR) of 94-544) so our study was situated in a fair position. The median age of individuals was 41 (IQR: 37-44). Generally, the frequency was higher in men than in women. As seen in Table 3, there are some similarities between our study and the Norwegian study in terms of gender and age. In our study early-onset CRC predominantly affected women, whereas late-onset ones mainly involved men, which was statistically significant. However, several studies have yielded conflicting results [46-49].

Our analysis revealed that CRC was less frequent in proximal colon, which is consistent with other authors $[50,51]$. With respect to age, there are commonly no significant differences in the distribution of tumour location in different age groups investigated [24,49,52,53], which is in accordance with our results that indicated rather identical distribution of distal tumours in both CRC groups under investigation (60.0\% vs. $61.2 \%)$. On the other hand, there are also multiple studies that do not support our findings $[46,47,54,55]$.

As mentioned earlier, there was a statistically significant difference in family history of CRC between two age categories. This factor accounts for around $20 \%$ of early-onset CRCs in our study. The results of recent researches have confirmed this observation $[47,56]$. Although FHC overall did not show statistical significance, a positive history of CRC in SDR, or the combination of either FDR or SDR, reached statistical significance. 
Table 3

Published literature on early-onset CRC

\begin{tabular}{|c|c|c|c|c|c|c|}
\hline $\begin{array}{l}\text { Study } \\
\text { reference }\end{array}$ & Year & Country & $\begin{array}{l}\text { Sample } \\
\text { size }(N)\end{array}$ & $\begin{array}{l}\text { Gender } \\
(\% \\
\text { males })\end{array}$ & $\begin{array}{l}\text { Age } \\
\text { (median[IQR]/mean } \\
\pm \text { SD) }\end{array}$ & $\begin{array}{l}\text { Age range and } \\
\text { proportion of early- } \\
\text { onset cases (\%) }\end{array}$ \\
\hline [3] & 2019 & Spain & 98 & $64.0 \%$ & $41.0 \pm 5.6$ & NA \\
\hline [11] & 2012 & $\begin{array}{l}\text { United } \\
\text { States }\end{array}$ & 64,068 & NA & 44.0 [NA] & $40-49(75 \%)$ \\
\hline [12] & 2020 & $\begin{array}{l}\text { United } \\
\text { States }\end{array}$ & 651 & $82.3 \%^{*}$ & $44.8 \pm 4.9$ & $40-49(85 \%)$ \\
\hline [13] & 2019 & $\begin{array}{l}\text { United } \\
\text { States }\end{array}$ & 1700 & $48.0 \%$ & 37.0 [NA] & $35-39(54 \%)$ \\
\hline [47] & 2013 & $\begin{array}{l}\text { United } \\
\text { States }\end{array}$ & 180 & $52.0 \%$ & $41.4 \pm 6.2$ & NA \\
\hline [57] & 2020 & Scotland & 172 & $52.0 \%$ & $47.7 \pm 6.1$ & $40-49(77 \%)$ \\
\hline [38] & 2018 & $\begin{array}{l}\text { United } \\
\text { States }\end{array}$ & 430,886 & NA & NA & NA \\
\hline [9] & 2014 & France & 1360 & $54.8 \%$ & NA & NA \\
\hline [10] & 2019 & Kazakhstan & 125 & $49.6 \%$ & 40.7 [17-50] & NA \\
\hline [58] & 2019 & Pakistan & 136 & $69.0 \%$ & $42.7 \pm N A$ & < $50(65 \%)$ \\
\hline [59] & 2020 & $\begin{array}{l}\text { United } \\
\text { States }\end{array}$ & 269 & $54.0 \%$ & $43 \pm 6$ & NA \\
\hline [31] & 2018 & Iran & 123 & $41.0 \%$ & $40.3 \pm 6.8$ & $40-50(55 \%)$ \\
\hline $\begin{array}{l}\text { This } \\
\text { study }\end{array}$ & 2020 & Iran & 222 & $44.1 \%$ & $40.3 \pm 7.3$ & $40-50(58 \%)$ \\
\hline
\end{tabular}

It has been observed that histology of tumours in younger patients are often more aggressive with poor differentiation in comparison with older patients $[60,61]$, which is generally negative for survival.

Nevertheless, the overall 5-year relative survival rate for patients under 50 years is not shorter on the whole than for patients above this age in spite of often presenting with more advanced disease [24, 27, $62,63]$. Indeed, sometimes even better, which is supported by our finding of significantly higher mortality for late-onset CRCs.

\section{Strengths and Limitations:}


The multicentre design with a relatively large number of patients, who were followed over a period of three years is a main strength of the present study. In addition, the study examines thoroughly the various features in terms of an age cut-off and living status. Missing values with respect to certain variables is the most challenging limitation, which was were handled by considering only what was available. Data, such as symptoms, socioeconomic status, BMI, past medical history, ethnicity, geographic and colonoscopy findings were not available and can therefore be counted as another limitation, as complete dataset would have made a more detailed interpretation possible.

\section{Conclusion:}

Although $58 \%$ of early-onset CRCs were between the ages of 40 and 50 , the incidence of early-onset CRC at also younger ages is not unusual highlighting the need for a well-defined algorithm assisting the identification of patients at risk for early-onset CRC. Furthermore, mismatch-repair deficiency in CRC patients was more common in those, who did not survive compared to those who did; however, this difference was only significant with respect to MLH1 and PMS2. In our study, women were in majority for early-onset CRC, while the opposite was the case for late-onset CRC. The incidence of CRC with distal tumours was frequently higher than for other sites in both early-onset CRC and late-onset CRC.

\section{Declarations}

\section{Ethics approval and consent to participate.}

The study was approved by Ethics committee of Mashhad University of Medical Sciences (ethics code: IR.MUMS.REC.1396.164) and conformed to the ethical principles contained in Declaration of Helsinki. For experiments involving human participants (including the use of tissue samples), the participants signed an informed consent before the study.

\section{Consent for publication.}

Not applicable.

\section{Availability of data and materials.}

Data will be provided upon request with the permission of the corresponding authors.

\section{Competing interests.}

The authors declare that they have no competing interests. 


\section{Funding.}

This study was supported by Mashhad University of Medical Sciences (grant number of 940610).

\section{Authors' contributions.}

$B H, L G$, and SE contributed to the study design. All authors (BH, ZR, LG, RB, FR, AG, KG, RD, and SE) contributed to data gathering and interpretation of the results. $\mathrm{ZR}, \mathrm{BH}$, and FR performed analyses and wrote the first draft of the manuscript. RB edited the final version of the manuscript. All authors $(B H, Z R$, $L G, R B, F R, A G, K G, R D$, and $S E$ ) read, commented, and approved the final manuscript.

\section{Acknowledgment.}

We would like to thank Mashhad University of Medical Sciences for its supports.

\section{References}

1. Rawla P, Sunkara T, Barsouk A. Epidemiology of colorectal cancer: Incidence, mortality, survival, and risk factors. Przegla囚d Gastroenterologiczny. 2019;14(2):89.

2. Bailey CE, Hu C-Y, You YN, Bednarski BK, Rodriguez-Bigas MA, Skibber JM, et al. Increasing disparities in the age-related incidences of colon and rectal cancers in the United States, 1975-2010. JAMA surgery. 2015;150(1):17-22.

3. Arriba M, Sánchez C, Vivas A, Nutu O, Rueda D, Tapial S, et al. Intermediate-onset colorectal cancer: A clinical and familial boundary between both early and late-onset colorectal cancer. PloS one. 2019;14(5).

4. Siegel RL, Jemal A, Ward EM. Increase in incidence of colorectal cancer among young men and women in the United States. Cancer Epidemiology and Prevention Biomarkers. 2009;18(6):1695-8.

5. Malekzadeh R, Bishehsari F, Mahdavinia M, Ansari R. Epidemiology and molecular genetics of colorectal cancer in iran: a review. 2009.

6. Siegel RL, Sahar L, Robbins A, Jemal A. Where can colorectal cancer screening interventions have the most impact? Cancer Epidemiology and Prevention Biomarkers. 2015;24(8):1151-6.

7. Sudarshan V, Hussain N, Gahine R, Mourya J. Colorectal cancer in young adults in a tertiary care hospital in Chhattisgarh, Raipur. Indian journal of cancer. 2013;50(4):337.

8. Zeinalian M, Hashemzadeh-Chaleshtori M, Akbarpour MJ, Emami MH. Epidemioclinical Feature of Early-Onset Colorectal Cancer at-Risk for Lynch Syndrome in Central Iran. Asian Pacific journal of cancer prevention: APJCP. 2015;16(11):4647-52.

9. Ferlay J, Soerjomataram I, Dikshit R, Eser S, Mathers C, Rebelo M, et al. Cancer incidence and mortality worldwide: sources, methods and major patterns in GLOBOCAN 2012. International journal 
of cancer. 2015;136(5):E359-E86.

10. Zhunussova G, Afonin G, Abdikerim S, Jumanov A, Perfilyeva A, Kaidarova D, et al. Mutation spectrum of cancer-associated genes in patients with early onset of colorectal cancer. Frontiers in oncology. 2019;9:673.

11. You YN, Xing Y, Feig BW, Chang GJ, Cormier JN. Young-onset colorectal cancer: is it time to pay attention? Archives of internal medicine. 2012;172(3):287-9.

12. Low EE, Demb J, Liu L, Earles A, Bustamante R, Williams CD, et al. Risk Factors for Early-Onset Colorectal Cancer. Gastroenterology. 2020.

13. Glover M, Mansoor E, Panhwar M, Parasa S, Cooper GS. Epidemiology of Colorectal Cancer in Average Risk Adults 20-39 Years of Age: A Population-Based National Study. Digestive diseases and sciences. 2019;64(12):3602-9.

14. De Silva M, Fernando M, Fernando D. Comparison of some clinical and histological features of colorectal carcinoma occurring in patients below and above 40 years. Ceylon Medical Journal. 2000;45(4):166-7.

15. Bray F, Ferlay J, Soerjomataram I, Siegel RL, Torre LA, Jemal A. Global cancer statistics 2018 : GLOBOCAN estimates of incidence and mortality worldwide for 36 cancers in 185 countries. CA: a cancer journal for clinicians. 2018;68(6):394-424. Epub 2018/09/13. doi: 10.3322/caac.21492. PubMed PMID: 30207593.

16. Schellerer V, Croner R, Langheinrich M, Hohenberger W, Merkel S. Colorectal Carcinoma in Young Patients-Is Age a Prognostic Factor? Zentralblatt fur Chirurgie. 2015;140(6):600-6.

17. Perea J, Rueda D, Canal A, Rodríguez Y, Álvaro E, Osorio I, et al. Age at onset should be a major criterion for subclassification of colorectal cancer. The Journal of Molecular Diagnostics. 2014;16(1):116-26.

18. Popat S, Hubner R, Houlston RS. Systematic review of microsatellite instability and colorectal cancer prognosis. Journal of clinical oncology : official journal of the American Society of Clinical Oncology. 2005;23(3):609-18. Epub 2005/01/22. doi: 10.1200/jco.2005.01.086. PubMed PMID: 15659508.

19. Chang DT, Pai RK, Rybicki LA, Dimaio MA, Limaye M, Jayachandran P, et al. Clinicopathologic and molecular features of sporadic early-onset colorectal adenocarcinoma: an adenocarcinoma with frequent signet ring cell differentiation, rectal and sigmoid involvement, and adverse morphologic features. Mod Pathol. 2012;25(8):1128-39. doi: 10.1038/modpathol.2012.61. PubMed PMID: 22481281.

20. Jandova J, Xu W, Nfonsam V. Sporadic early-onset colon cancer expresses unique molecular features. J Surg Res. 2016;204(1):251-60. doi: 10.1016/j.jss.2016.04.068. PubMed PMID: 27451894.

21. Pilozzi E, Lorenzon L, Lo Baido S, Ferri M, Duranti E, Fochetti F, et al. Left-sided early onset colorectal carcinomas: A sporadic neoplasm with aggressive behavior. Am J Surg. 2017;214(3):421-7. doi: 10.1016/j.amjsurg.2017.01.035. PubMed PMID: 28173936.

22. Stigliano V, Sanchez-Mete L, Martayan A, Anti M. Early-onset colorectal cancer: a sporadic or inherited disease? World J Gastroenterol. 2014;20(35):12420-30. doi: 10.3748/wjg.v20.i35.12420. 
PubMed PMID: 25253942; PubMed Central PMCID: PMCPMC4168075.

23. Zeinalian M, Hashemzadeh-Chaleshtori M, Akbarpour MJ, Emami MH. Epidemioclinical Feature of Early-Onset Colorectal Cancer at-Risk for Lynch Syndrome in Central Iran. Asian Pacific Journal of Cancer Prevention. 2015;16(11):4647-52. doi: 10.7314/apjcp.2015.16.11.4647.

24. Schellerer V, Croner R, Langheinrich M, Hohenberger W, Merkel S. [Colorectal Carcinoma in Young Patients - Is Age a Prognostic Factor?]. Zentralblatt fur Chirurgie. 2015;140(6):600-6. Epub 2013/07/13. doi: 10.1055/s-0032-1328570. PubMed PMID: 23846539.

25. Mahdavinia M, Bishehsari F, Ansari R, Norouzbeigi N, Khaleghinejad A, Hormazdi M, et al. Family history of colorectal cancer in Iran. BMC Cancer. 2005;5:112. doi: 10.1186/1471-2407-5-112. PubMed PMID: 16143045; PubMed Central PMCID: PMCPMC1208868.

26. Kurzawski G, Suchy J, Debniak T, Kladny J, Lubinski J. Importance of microsatellite instability (MSI) in colorectal cancer: MSI as a diagnostic tool. Ann Oncol. 2004;15 Suppl 4:iv283-4. doi: 10.1093/annonc/mdh940. PubMed PMID: 15477322.

27. Lee PY, Fletcher WS, Sullivan ES, Vetto JT. Colorectal cancer in young patients: characteristics and outcome. The American surgeon. 1994;60(8):607-12. Epub 1994/08/01. PubMed PMID: 8030817.

28. Perea J, Rueda D, Canal A, Rodriguez Y, Alvaro E, Osorio I, et al. Age at onset should be a major criterion for subclassification of colorectal cancer. J Mol Diagn. 2014;16(1):116-26. doi: 10.1016/j.jmoldx.2013.07.010. PubMed PMID: 24184227.

29. Dolatkhah R, Somi MH, Bonyadi MJ, Asvadi Kermani I, Farassati F, Dastgiri S. Colorectal cancer in iran: molecular epidemiology and screening strategies. J Cancer Epidemiol. 2015;2015:643020. doi: 10.1155/2015/643020. PubMed PMID: 25685149; PubMed Central PMCID: PMCPMC4312646.

30. Soliman AS, Bondy ML, El-Badawy SA, Mokhtar N, Eissa S, Bayoumy S, et al. Contrasting molecular pathology of colorectal carcinoma in Egyptian and Western patients. British journal of cancer. 2001;85(7):1037-46. Epub 2001/10/11. doi: 10.1038/sj.bjc.6691838. PubMed PMID: 11592777; PubMed Central PMCID: PMCPMC2375101.

31. Goshayeshi L, Ghaffarzadegan K, Khooei A, Esmaeilzadeh A, Rahmani Khorram M, Mosannen Mozaffari $\mathrm{H}$, et al. Prevalence and clinicopathological characteristics of mismatch repair-deficient colorectal carcinoma in early onset cases as compared with late-onset cases: a retrospective crosssectional study in Northeastern Iran. BMJ open. 2018;8(8):e023102. Epub 2018/09/01. doi: 10.1136/bmjopen-2018-023102. PubMed PMID: 30166308; PubMed Central PMCID: PMCPMC6119423.

32. Goshayeshi L, Khooiee A, Ghaffarzadegan K, Rahmani Khorram M, Bishehsari F, Hoseini B, et al. Screening for Lynch Syndrome in Cases with Colorectal Carcinoma from Mashhad. Archives of Iranian medicine. 2017;20(6):332-7. Epub 2017/06/26. PubMed PMID: 28646840.

33. Khorram MR, Goshayeshi L, Maghool F, Bergquist R, Ghaffarzadegan K, Eslami S, et al. Prevalence of Mismatch Repair-Deficient Colorectal Adenoma/Polyp in Early-Onset, Advanced Cases: a CrossSectional Study Based on Iranian Hereditary Colorectal Cancer Registry. Journal of gastrointestinal cancer. 2020. Epub 2020/03/21. doi: 10.1007/s12029-020-00395-y. PubMed PMID: 32193764. 
34. Vasen HF, Watson P, Mecklin JP, Lynch HT. New clinical criteria for hereditary nonpolyposis colorectal cancer (HNPCC, Lynch syndrome) proposed by the International Collaborative group on HNPCC. Gastroenterology. 1999;116(6):1453-6. Epub 1999/05/29. doi: 10.1016/s0016-5085(99)70510-x. PubMed PMID: 10348829.

35. Umar A, Boland CR, Terdiman JP, Syngal S, de la Chapelle A, Rüschoff J, et al. Revised Bethesda Guidelines for hereditary nonpolyposis colorectal cancer (Lynch syndrome) and microsatellite instability. Journal of the National Cancer Institute. 2004;96(4):261-8. Epub 2004/02/19. doi: 10.1093/jnci/djh034. PubMed PMID: 14970275; PubMed Central PMCID: PMCPMC2933058.

36. Russo A, Andreano A, Sartore-Bianchi A, Mauri G, Decarli A, Siena S. Increased incidence of colon cancer among individuals younger than 50 years: A 17 years analysis from the cancer registry of the municipality of Milan, Italy. Cancer epidemiology. 2019;60:134-40.

37. Bailey CE, Hu CY, You YN, Bednarski BK, Rodriguez-Bigas MA, Skibber JM, et al. Increasing disparities in the age-related incidences of colon and rectal cancers in the United States, 1975-2010. JAMA Surg. 2015;150(1):17-22. doi: 10.1001/jamasurg.2014.1756. PubMed PMID: 25372703; PubMed Central PMCID: PMCPMC4666003.

38. Jacobs D, Zhu R, Luo J, Grisotti G, Heller DR, Kurbatov V, et al. Defining Early-Onset Colon and Rectal Cancers. Front Oncol. 2018;8:504. Epub 2018/11/22. doi: 10.3389/fonc.2018.00504. PubMed PMID: 30460196; PubMed Central PMCID: PMCPMC6232522.

39. Ansari R, Mahdavinia M, Sadjadi A, Nouraie M, Kamangar F, Bishehsari F, et al. Incidence and age distribution of colorectal cancer in Iran: results of a population-based cancer registry. Cancer letters. 2006;240(1):143-7. Epub 2005/11/18. doi: 10.1016/j.canlet.2005.09.004. PubMed PMID: 16288832.

40. Malekzadeh R, Bishehsari F, Mahdavinia M, Ansari R. Epidemiology and molecular genetics of colorectal cancer in iran: a review. Archives of Iranian medicine. 2009;12(2):161-9. Epub 2009/03/03. PubMed PMID: 19249887.

41. Mousavi SM, Gouya MM, Ramazani R, Davanlou M, Hajsadeghi N, Seddighi Z. Cancer incidence and mortality in Iran. Ann Oncol. 2009;20(3):556-63. Epub 2008/12/17. doi: 10.1093/annonc/mdn642. PubMed PMID: 19073863.

42. Fazeli MS, Adel MG, Lebaschi AH. Colorectal carcinoma: a retrospective, descriptive study of age, gender, subsite, stage, and differentiation in Iran from 1995 to 2001 as observed in Tehran University. Diseases of the colon and rectum. 2007;50(7):990-5. Epub 2007/05/26. doi: 10.1007/s10350-0070248-z. PubMed PMID: 17525859.

43. Azadeh S, Moghimi-Dehkordi B, Fatem SR, Pourhoseingholi MA, Ghiasi S, Zali MR. Colorectal cancer in Iran: an epidemiological study. Asian Pacific journal of cancer prevention : APJCP. 2008;9(1):123-6. Epub 2008/04/29. PubMed PMID: 18439090.

44. Siegel R, Desantis C, Jemal A. Colorectal cancer statistics, 2014. CA: a cancer journal for clinicians. 2014;64(2):104-17. Epub 2014/03/19. doi: 10.3322/caac.21220. PubMed PMID: 24639052.

45. Sung JJ, Lau JY, Goh KL, Leung WK. Increasing incidence of colorectal cancer in Asia: implications for screening. The Lancet Oncology. 2005;6(11):871-6. Epub 2005/11/01. doi: 10.1016/s1470- 
2045(05)70422-8. PubMed PMID: 16257795.

46. Sudarshan V, Hussain N, Gahine R, Mourya J. Colorectal cancer in young adults in a tertiary care hospital in Chhattisgarh, Raipur. Indian J Cancer. 2013;50(4):337-40. doi: 10.4103/0019509X.123621. PubMed PMID: 24369213.

47. Myers EA, Feingold DL, Forde KA, Arnell T, Jang JH, Whelan RL. Colorectal cancer in patients under 50 years of age: a retrospective analysis of two institutions' experience. World J Gastroenterol. 2013;19(34):5651-7. Epub 2013/09/17. doi: 10.3748/wjg.v19.i34.5651. PubMed PMID: 24039357; PubMed Central PMCID: PMCPMC3769901.

48. Parramore JB, Wei JP, Yeh KA. Colorectal cancer in patients under forty: presentation and outcome. The American surgeon. 1998;64(6):563-7; discussion 7-8. Epub 1998/06/10. PubMed PMID: 9619179.

49. de Silva MV, Fernando MS, Fernando D. Comparison of some clinical and histological features of colorectal carcinoma occurring in patients below and above 40 years. The Ceylon medical journal. 2000;45(4):166-8. Epub 2001/04/11. PubMed PMID: 11293963.

50. Dozois EJ, Boardman LA, Suwanthanma W, Limburg PJ, Cima RR, Bakken JL, et al. Young-onset colorectal cancer in patients with no known genetic predisposition: can we increase early recognition and improve outcome? Medicine. 2008;87(5):259.

51. Strum WB, Boland CR. Clinical and Genetic Characteristics of Colorectal Cancer in Persons under 50 Years of Age: A Review. Digestive diseases and sciences. 2019:1-7.

52. Minardi AJ, Jr., Sittig KM, Zibari GB, McDonald JC. Colorectal cancer in the young patient. The American surgeon. 1998;64(9):849-53. Epub 1998/09/10. PubMed PMID: 9731812.

53. Chiang JM, Chen MC, Changchien CR, Chen JS, Tang R, Wang JY, et al. Favorable influence of age on tumor characteristics of sporadic colorectal adenocarcinoma: patients 30 years of age or younger may be a distinct patient group. Diseases of the colon and rectum. 2003;46(7):904-10. Epub 2003/07/09. doi: 10.1097/01.dcr.0000075210.01797.11. PubMed PMID: 12847364.

54. Palmer ML, Herrera L, Petrelli NJ. Colorectal adenocarcinoma in patients less than 40 years of age. Diseases of the colon and rectum. 1991;34(4):343-6. Epub 1991/04/01. PubMed PMID: 1706654.

55. Fante R, Benatti P, di Gregorio C, De Pietri S, Pedroni M, Tamassia MG, et al. Colorectal carcinoma in different age groups: a population-based investigation. The American journal of gastroenterology. 1997;92(9):1505-9. Epub 1997/10/08. PubMed PMID: 9317073.

56. Makela JT, Kiviniemi H. Clinicopathological features of colorectal cancer in patients under 40 years of age. International journal of colorectal disease. 2010;25(7):823-8. Epub 2010/03/11. doi: 10.1007/s00384-010-0914-9. PubMed PMID: 20217423.

57. Perrott S, Laurie K, Laws K, Johnes A, Miedzybrodzka Z, Samuel L. Young-onset colorectal cancer in the North East of Scotland: survival, clinico-pathological features and genetics. BMC cancer. 2020;20(1):108.

58. Rashid MU, Naeemi H, Muhammad N, Loya A, Lubiński J, Jakubowska A, et al. Prevalence and spectrum of MLH1, MSH2, and MSH6 pathogenic germline variants in Pakistani colorectal cancer 
patients. Hereditary cancer in clinical practice. 2019;17(1):29.

59. Gausman V, Dornblaser D, Anand S, Hayes RB, O'Connell K, Du M, et al. Risk Factors Associated With Early-Onset Colorectal Cancer. Clin Gastroenterol Hepatol. 2020;18(12):2752-9.e2. Epub 2019/10/18. doi: 10.1016/j.cgh.2019.10.009. PubMed PMID: 31622737; PubMed Central PMCID: PMCPMC7153971.

60. Endreseth BH, Romundstad P, Myrvold HE, Hestvik UE, Bjerkeset T, Wibe A. Rectal cancer in the young patient. Diseases of the colon and rectum. 2006;49(7):993-1001. Epub 2006/06/03. doi: 10.1007/s10350-006-0558-6. PubMed PMID: 16741599.

61. Moore PA, Dilawari RA, Fidler WJ. Adenocarcinoma of the colon and rectum in patients less than 40 years of age. The American surgeon. 1984;50(1):10-4. Epub 1984/01/01. PubMed PMID: 6691626.

62. Leff DR, Chen A, Roberts D, Grant K, Western C, Windsor AC, et al. Colorectal cancer in the young patient. The American surgeon. 2007;73(1):42-7. Epub 2007/01/26. PubMed PMID: 1724945.

63. Eker B, Ozaslan E, Karaca H, Berk V, Bozkurt O, Inanc M, et al. Factors affecting prognosis in metastatic colorectal cancer patients. Asian Pacific journal of cancer prevention : APJCP. 2015;16(7):3015-21. Epub 2015/04/10. PubMed PMID: 25854399.

\section{Figures}


Assessed for eligibility $(\mathrm{N}=648)$

All CRC patients referred from January 2014 to February 2017 to the following centres:

-Imam Reza Hospital Laboratory $(\mathrm{N}=285)$

-Mashhad Pathology Laboratory $(\mathrm{N}=240)$

-Moayed Pathology Lab oratory $(\mathrm{N}=123)$

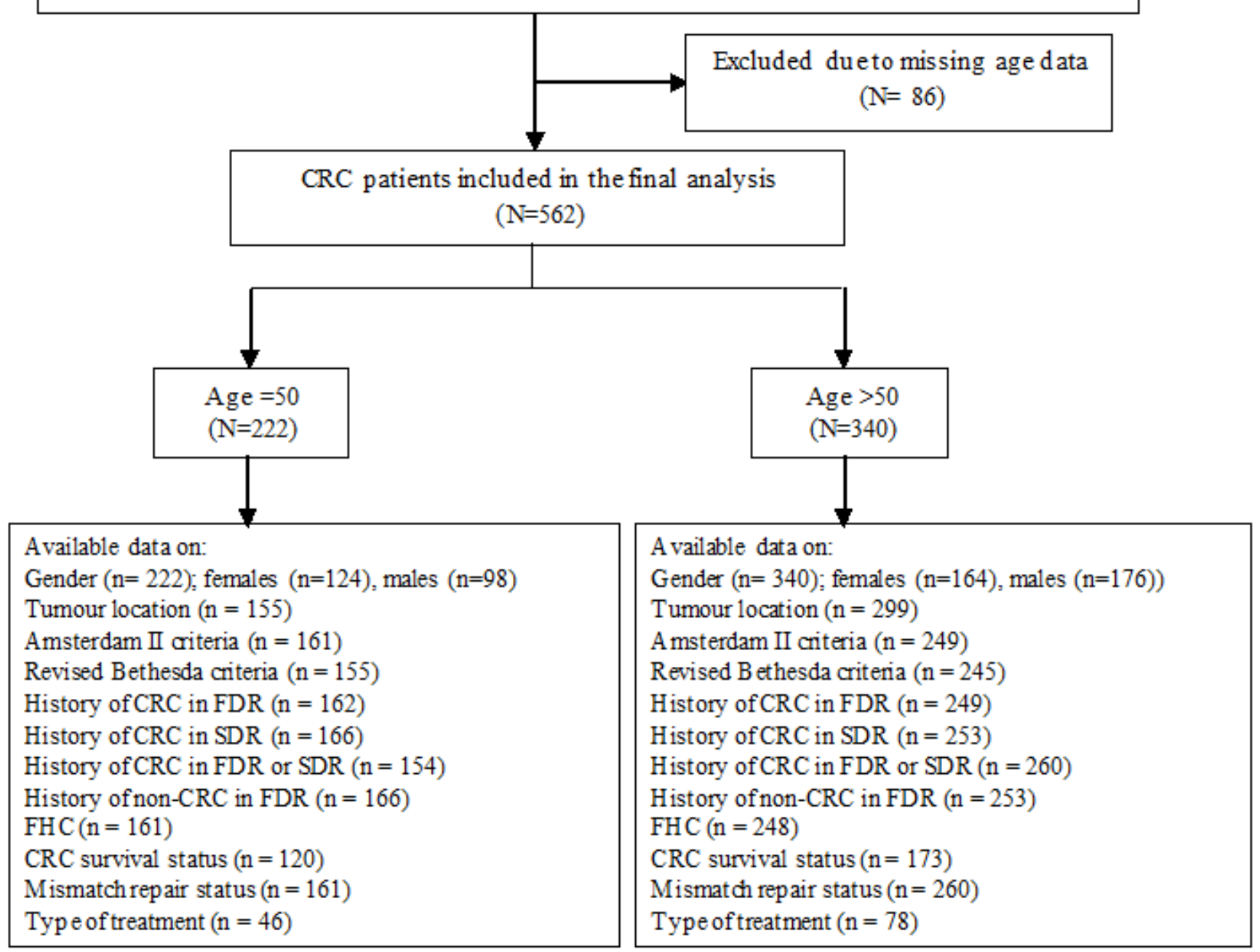

\section{Figure 1}

Schematic diagram of the inclusion/exclusion process; $\mathrm{CRC}=$ Colorectal Cancer; FDR=First Degree Relatives; SDR=Second Degree Relatives; FHC=Family History of Cancer.

\section{Supplementary Files}

This is a list of supplementary files associated with this preprint. Click to download.

- ANNEX.docx 